HOW TO THINK LIKE

AN ANTHROPOLOGIST 



\section{MATTHEW ENGELKE}

\section{How to Think Like an Anthropologist}

PRINCETON UNIVERSITY PRESS

PRINCETON AND OXFORD 
Copyright (C) 2018 by Matthew Engelke

Requests for permission to reproduce material from this work should be sent to Permissions, Princeton University Press

Published in the United States, its territories, and dependencies by

Princeton University Press, 41 William Street, Princeton, New Jersey 08540

press.princeton.edu

Jacket pattern courtesy of Shutterstock

The author has asserted his moral rights. All rights reserved

First published in Great Britain in 2017 as Think Like an Anthropologist by the Penguin Group, Penguin Books Ltd, 80 Strand, London WC2R ORL, England. Copyright (C) 2017 by Matthew Engelke

ISBN 978-0-691-17878-3

Library of Congress Control Number 2017958316

This book has been composed in Sabon LT Std and DIN Pro

Printed on acid-free paper. $\infty$

Printed in the United States of America

10987654321 